\title{
Planning and Marketing the City for Sustainability: The Madrid Nuevo Norte Project
}

\author{
Theodore Metaxas ${ }^{1, * \mathbb{D} \text {, Laura Juarez }}{ }^{2}$ and Gaby Gavriilidis ${ }^{1}$ \\ 1 Department of Economics, University of Thessaly, 38333 Volos, Greece; gavriilidis.gabi@gmail.com \\ 2 Department of Marketing and Communication, European University of Madrid, 28224 Madrid, Spain; \\ laura.juarez@universidadeuropea.es \\ * Correspondence: metaxas@uth.gr
}

check for updates

Citation: Metaxas, T.; Juarez, L.; Gavriilidis, G. Planning and Marketing the City for Sustainability: The Madrid Nuevo Norte Project. Sustainability 2021, 13, 2094.

https://doi.org/10.3390/su13042094

Academic Editor: Christopher Robin Bryant

Received: 30 December 2020

Accepted: 12 February 2021

Published: 16 February 2021

Publisher's Note: MDPI stays neutral with regard to jurisdictional claims in published maps and institutional affiliations.

Copyright: (c) 2021 by the authors. Licensee MDPI, Basel, Switzerland. This article is an open access article distributed under the terms and conditions of the Creative Commons Attribution (CC BY) license (https:// creativecommons.org/licenses/by/ $4.0 /)$.

\begin{abstract}
Madrid Nuevo Norte (Madrid New North) is an urban redevelopment program applied in the city of Madrid in Spain. Regarding this, the aim of this paper is twofold: firstly, the project examines if the Nuevo Norte project is aligned with the principles of sustainability. Secondly, the paper investigates the impact of Nuevo Norte on the application of city marketing strategies in Madrid. For those purposes, questionnaires were distributed through the Internet to 122 urban developers and planners located in the Spanish capital. The results indicated that overall, Nuevo Norte contributes to the sustainable development of Madrid; however, concerns were identified regarding the budget and the timeline of the project. In addition, Madrid Nuevo Norte provides significant opportunities to local authorities to implement sustainable city marketing strategies, aiming to improve the competitiveness and the quality of life in the city of Madrid. To this end, it seems that city marketing, through the construction of mega projects, should contribute to sustainability, ensuring a better life for local residents and communities in general. The research is expected to assist local authorities in Spain to harness the potential of mega projects such as Nuevo Norte in designing city marketing strategies and to promote Madrid in an international context as a city that gives emphasis in urban sustainability.
\end{abstract}

Keywords: city marketing; sustainability; mega project; Nuevo Norte Madrid; research

\section{Introduction}

In the post-industrial era, marketing techniques have been recruited to help toward the regeneration of industrial cities, especially in Europe [1]. It is no longer surprising that successful implementation of a wider urban development plan or regeneration effort is commonly connected with a city marketing plan [2]. Therefore, city marketing should not be detached from the city's actual development [3] and its sustainability [2]. To this particular point, the importance of mega infrastructure projects is crucial for urban sustainability achievement [4]. A mega project can be perceived either as a single infrastructure project such as a sport stadium or transportation facilities, or as a more complex infrastructure such as land-use remodeling initiatives such as slum redevelopments [5]. In this study, the Madrid Nuevo Norte Project (MNNP) is examined. More particularly, the aim of this paper is twofold: firstly, the study examines if the Nuevo Norte project is aligned with the principles of sustainability. Secondly, the paper investigates the impact of Nuevo Norte on the application of city marketing strategies in Madrid. More particularly, the paper tries to provide answers to the following research questions: (a) Is MNNP aligned with the criteria of sustainability (economic, environmental and social)? and (b) Does MNNP contribute to the implementation of sustainable city marketing strategies in the region of Madrid? For these purposes, questionnaires were distributed through the Internet to 122 urban developers, sustainability experts and planners located in Madrid. The structure of the paper is the following: The second section presents the literature review regarding the main terms of urban sustainability, city marketing and its relationship with sustainable 
development, and finally the role of mega projects. The third section focuses on the Madrid Nuevo Norte Project, presenting its character and recognizing some sustainability issues related to the project. The fourth section provides the research methodology of the project, while the fifth describes the statistical analysis of the data. The sixth section provides answers to research questions, while the last section outlines the conclusions of the study.

\section{Literature Review}

\subsection{Urban Sustainability in Brief}

There is a growing attention in the literature toward the issue of urban sustainability. Cities have become more complex systems [6], calling on practitioners and academics to reconsider their efficient management in the context of sustainability. Indicatively, Zhang and $\mathrm{Li}$ (2018) define urban sustainability (US) as: "the active process of synergetic integration and co-evolution between the subsystems making up a city without compromising the possibilities for development of surrounding areas and contributing by this means toward reducing the harmful effects of development on the biosphere" [7]. From this definition is derived that US includes several dimensions that reflect its wide concept, namely, environmental protection and restoration, local governance, housing, climate change issues, quality of life in the community, built environment, city infrastructures, usage of natural resources, mobility and sustainable transportation, safety, usage of technology, preservation of public space, cultural and natural heritage, etc. [8-11]. These aspects should be addressed by urban planners and local governors.

\subsection{City Marketing as a Strategic Planning Process for Urban Sustainable Development}

The relation between city/urban planning and "winning strategies" such as place marketing and branding or new forms of strategic planning, in the context of the competitionoriented spatial economy, has been a popular research area in the last two decades [12-17]. Since 2000 urban planning has been expanded for many scholars to incorporate place marketing, with city/urban planning no longer limited to spatial and infrastructure dimensions, with socioeconomic factors becoming vital in urban programs [18-21].

The concept of strategic planning has been widely studied by academics in the area of business, and it has been widely utilized in both the private and public sectors [22]. Strategic planning is defined as the formulation of long-term organizational goals and objectives, including the selection of the appropriate strategies to achieve these goals and objectives [23]. In addition, it has been identified as an important process, especially in the area of local development and community economy, since public-private partnerships are based on the representation of common interests in order to define the development goals and motives, which in most cases have different characters [24,25].

On the other hand, place/city marketing as a strategic planning process can be understood as a "survival" reaction of cities to a new environment. Cities are now facing new challenges, including the increased mobility of capital, the easier relocation of economic activity, the radical development of the knowledge-based society and increased global connectivity [26]. In a broader approach, city marketing may be better suited to the notion of a city's overall management [27]. However, city marketing should focus on people and create a worthwhile living, visiting and/or investing place [28]. We now live in the era of city specialization [29]. City marketing is not only promotional actions for the city's image [16], and it is much more than the campaigns and logos [30]. It should be considered as a strategic tool with achievable objectives to match the appropriate demand and supply in a well-defined target market [31].

\subsection{The Role of Mega Infrastructure Projects}

All mega projects aim for urban development and competitiveness; thus, they are located or built in cities or city regions [26] and require the cooperation of the public and private sectors [32]. According to Theurillat and Crevoisier (2013), there are four phases in the production of mega projects [33]. The pre-project phase includes the resolution of all 
the territorial issues, such as the land availability and the urban policy frameworks. The next phase is the project development phase, which includes all the necessary actions from the initial design to the finalized concept of the project. Third is the project construction phase, and ultimately is the operational phase of the project. As we can understand, the importance and the complexity of the development of such mega projects require a dynamic and ambidextrous way of thinking around the projects and the way they are completed [34].

The complexity and the size of mega projects make them inherently tied to the logic of urban growth and development, which leads to wealth creation, prosperity, and urban qualitative transformation [35]. However, mega projects often involve negatives. According to Pitsis et al. [34], in a period when resources are limited and environmental concerns dominate, mega projects are also seen as destructive forces of doom and massive failure, which calls into question their sustainability. The international experience is rich in successful and failed examples of mega projects. Sihlcity in Zurich is perceived as a successful mega project example, especially for its financial sustainability and the public and private sector collaboration. The knowledge of its territorial context and its characteristics helped establish territorial sustainability and the investment to go forward [33]. Furthermore, in several mega projects in New York, Paris, and Sao Paolo, the city was willing to finance the initial investment, which seemed to improve the urban infrastructures [32]. On the other hand, in the Arab states of the Gulf region, some mega projects have been promoted as "green megaprojects." However, several economic, environmental, and social threats question the effectiveness of changing their current unsustainable urban developing pattern [36]. Nevertheless, mega projects can be seen as opportunities for all the stakeholders to achieve a broader awareness of urban sustainability issues.

\section{Madrid and MNNP}

According to Moreno-Jimenez et al. [37], the way we understand social and physical development has evolved over time. Today there is a community awareness that shares relevant social principles such as quality of life, sustainability, social and territorial cohesion, competitiveness, social empowerment, participation and responsibility, etc.

The city of Madrid faces one of its greatest challenges: to achieve a sustainable and efficient urban structure that is respectful toward the environment. There is a long way to go, but Madrid's Council, led by José Luis Martínez-Almeida, will focus all its efforts and a large part of its resources on meeting this challenge because the sustainability of cities is no longer understood in any other way, not individually, not at the national level, much less at the international level [38].

\subsection{Definition of the Project}

MNNP can be considered as the largest urban transformation project in a European capital [39]. It will occupy an area of 3.3 million square meters and will modify a large part of the northern area of the city of Madrid. New spaces for public use, office buildings, commercial areas, homes, infrastructure and green areas will be created. It is expected that $76 \%$ of the total space will be designed for public use. The approval of the project has had the participation and consensus of all the public administrations involved and the majority of the neighborhood associations. During the approval and urban design phase, citizen participation processes were opened, which served to modify some of the initial forecasts. The promotion of the project was assumed by the company Castellana Distrito Norte (DCN).

The central point of the project is the Chamartín train station, which will be remodeled and turned into the main axis of the Spanish high-speed network. In addition to this action, a business center will be built near the station, and the areas of Malmea, San Roque and Tres Olivos will be transformed, and the western sector of Las Tablas. The Chamartín station will have a large transport interchange, which will include urban and inter-urban buses; 
commuter, long-distance and high-speed trains; and transportation to Madrid Barajas airport, which can be reached in $15 \mathrm{~min}$.

The green areas will occupy 0.4 million square meters. A new park will be created close to Chamartín, which will cover the network of railway lines that arrive at the station. The rest of the green areas will be joined to form a south-north corridor that will reach Monte de El Pardo, one of the spaces with the greatest ecological value in the Community of Madrid. Ten thousand homes will be built, of which $20 \%$ will be for public housing. As in the rest of the planned buildings, all the homes will have high energy efficiency, both in construction and in their subsequent use. The new business center will employ approximately 130,000 people. The construction of three large office towers, more than $200 \mathrm{~m}$ high, is expected to be integrated into the green spaces and commercial areas [40]. Figure 1 presents the location and connections to the main transport networks of MNNP.

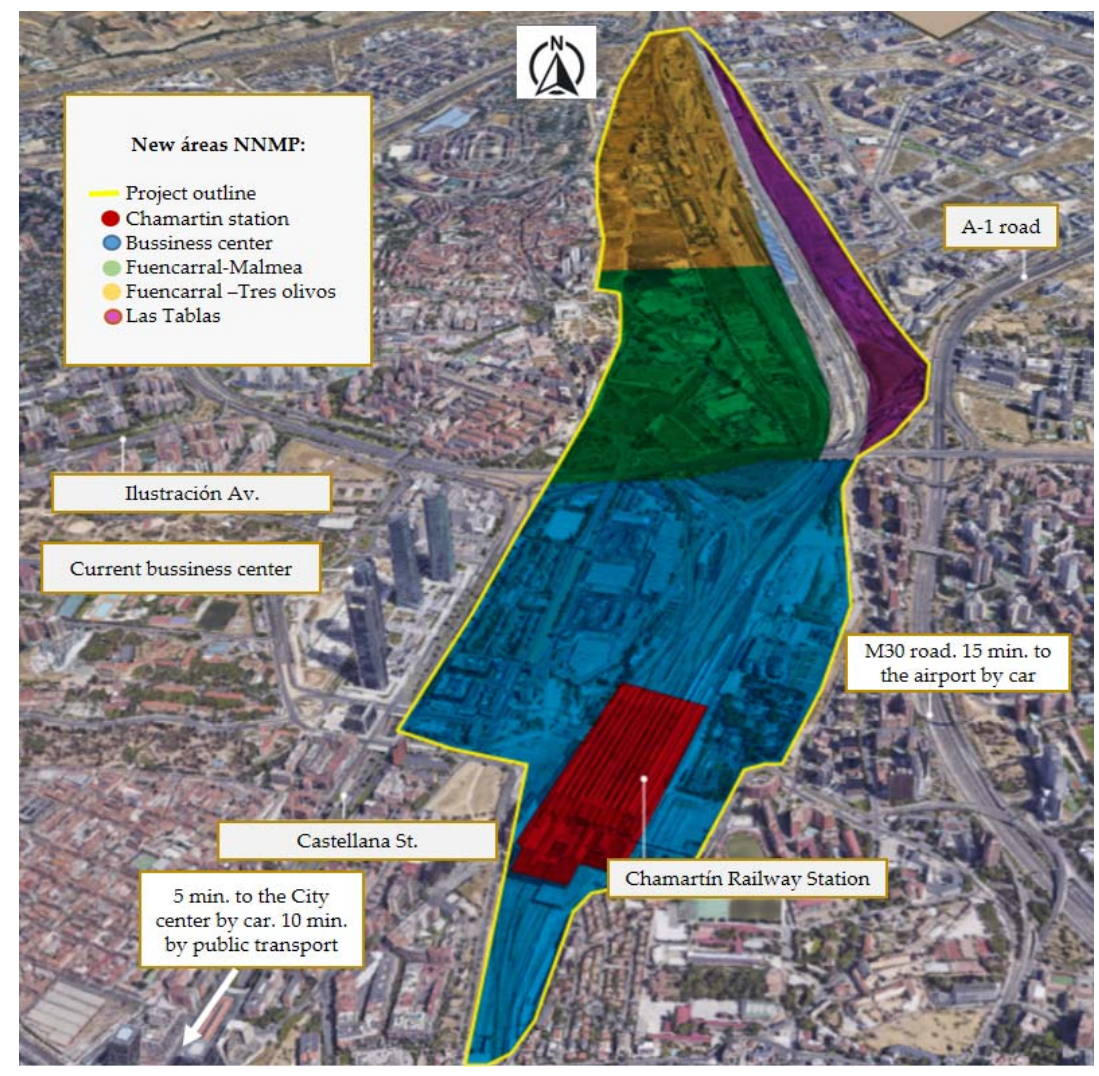

Figure 1. Madrid Nuevo Norte Project (MNNP) map. Location and connections to the main transport networks. Source: Expansión [41].

\subsection{Issues of Sustainability}

The commitment to sustainability is an essential and inherent value of MNNP, especially in environmental, economic and social terms [42]. MNNP has made sustainability one of the pillars of its planning, and therefore has adopted the 2030 Agenda, in which the UN established 17 Sustainable Development Goals (SDGs) (Figure 2) [43] as a guide to materialize that purpose. The plan addresses 12 SDG objectives and provides proposals at all points of the international road map that are likely to be applied in the scope of the project [44].

Within these 12 objectives, MNNP has placed special emphasis on four, mainly because they are considered critical and also for their greater capacity to act from urban design: water and sanitation management (SDG 6), the non-use of -energy pollutants (SDG 7), the creation of a sustainable urban environment (SDG 11) and climate action (SDG 13). Below are the 12 objectives applied in the project: 
Health and Well-being (SDG 3): Health, well-being and sustainable development are considered to be intrinsically connected; health is regarded as a precondition indicator, and as an outcome of successful sustainable development [45].

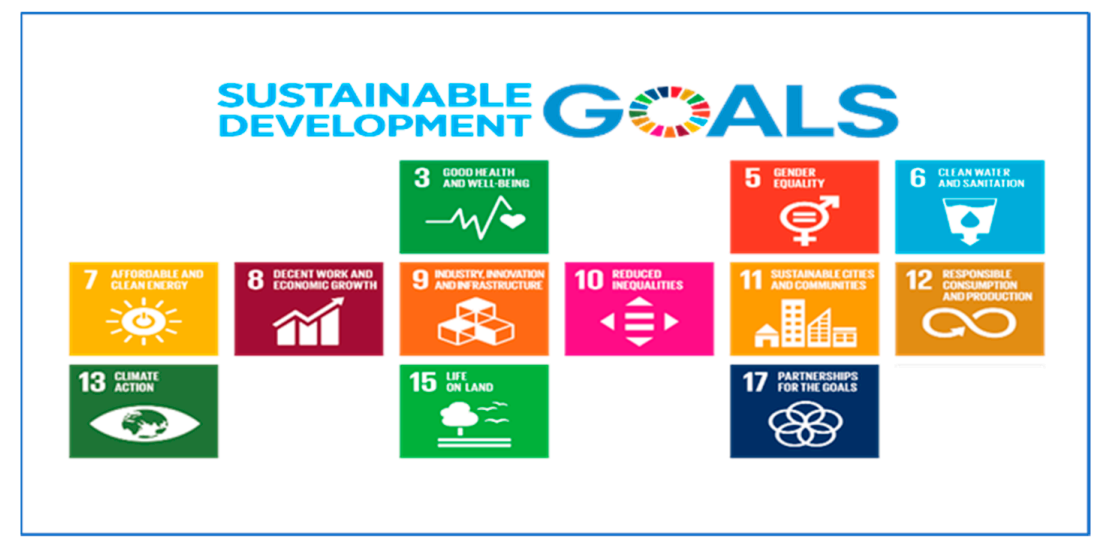

Figure 2. Madrid Nuevo Norte, sustainable development goals applied to the project. Source: https:/ / unstats.un.org/sdgs/report/2020/. (2020).

According to this approach, the project has a bioclimatic design, drawing comfortable streets and squares for citizens with shaded spaces and protection against the wind. The objective is to promote the use of public spaces and active urban life, which encourages common activities and the socialization of the people who share them. One of the most important factors in achieving this goal is the way we move in our daily lives; the promotion of mobility on foot and by bicycle will encourage daily physical activity. A city that encourages exercise on daily commutes is promoting heart-healthy activity; these aspects will turn into an improvement of the air quality and a reduction of environmental noise. The commitment to public transportation will also help to enhance air quality, reduce noise, and air pollution.

Gender equality (SDG 5): Inherent to sustainability is the notion of equity and social justice, which encapsulates gender equality [46]. MNNP has been a pioneer in gender equality applied to urban planning. It is the first major development in Spain that has incorporated a specific and planned gender study since its establishment. This study focuses on implementing measures to reduce gender gaps in mobility, safety and access to equipment. Inclusive coexistence was taken into account in the design of the spaces, according to the surveys and previous studies carried out among citizens. In accord with these premises, the urban model proposed by Madrid Nuevo Norte is a compact city, with short distances and relative density and a variety of green public and safe spaces spread around the Madrid Nuevo Norte areas. In addition, from a gender perspective, the width and night lighting of the sidewalks are also valued.

Efficient water management (SDG 6): According to Kayaga [47], there is a need for water professionals to change the way of water management resources in urban areas to ensure economic and environmental sustainability. The planning of MNNP has given special importance to the supply and management of water, implementing measures for its reuse and improving the efficiency of its use in buildings and infrastructures. The project incorporates large-scale water reuse systems, which include the comprehensive management of its collection, retention and reuse. Likewise, it is planned to use gray water and rainwater for the irrigation of green areas. The recovered water network will also serve for street cleaning. On the other hand, thanks to MNNP, $13 \mathrm{~km}$ of pre-existing facilities will be renovated, in a section that supplies $80 \%$ of the drinking water network of the city of Madrid. In this context, Madrid has the opportunity to become a reference in "water sensitive" urban design that will meet some of the challenges of climate change, such as reducing the city's vulnerability to flooding and maintaining water resources from an environmental, social and economic perspective. 
Climate forecasts show that total precipitation in Spain will decrease by $10 \%$ and droughts will become more frequent and more intense. The intensity of torrential rains will also increase, leading to a greater risk of flooding.

Therefore, it is essential to link the urban development of Madrid Nuevo Norte to these future circumstances, focusing on the water cycle, planning and managing its efficient and sustainable use. The maximum possible water self-sufficiency will be sought by combining catchment measures with saving and efficiency measures.

Clean Energy (SDG 7): The need for energy to satisfy socioeconomic development, welfare and health is growing over time. Returning to renewables can help to relieve climate change and is an excellent opportunity that needs to be sustainable in order to meet the energy demand of future generations [48]. At this point, the project plans the incorporation of sustainable and electrified means of transport, eliminating transport by energy of fossil origin. Likewise, the construction of highly demanding buildings in terms of energy efficiency is expected. The levels of demand will be higher than those existing in buildings with zero consumption. In fact, up to twice as much renewable energy will be generated in private buildings and up to four times in public ones.

Within the sustainable mobility strategy, the project planned the necessary infrastructures to make possible the incorporation of driverless electric buses. Charging points for electric vehicles are also planned, with the objective that $80 \%$ of trips for labor reasons will be made in non-polluting vehicles, including electric bicycles. The new project plans to expand the recharging network of the Madrid electric bicycle system named Bicimad. It is expected that the use of electric free-floating car sharing systems, currently used in the city [49-51], will be general and also contribute to the objectives of sustainability and low air pollution.

Since 2014, Madrid City has been developing a Sustainable Urban Mobility Plan (SUMP), promoted by the European Union [52]. This circumstance will have a positive influence on the level of sustainability of the project because the infrastructures and models already created by the plan are expected to be used and expanded. In particular, the current plan is focused on the promotion of pedestrian mobility, the promotion of cyclist mobility, the promotion of mobility by motorcycle, the optimization of the taxi service, the promotion of collective public transport, the incorporation of new models of collaborative mobility, improvements in mobility management, the improvement of accessibility to all modes of transportation, and the promotion of clean energy in vehicle technologies, among others [53].

Economic growth and quality employment (SDG 8): It is clear that there is a new generation of policy-aware smart cities geared toward socially inclusive economic growth and employment for sustainability [54]. The urban model of MNNP promotes sustainable and long-term economic growth. The modern business center that will promote innovation and the knowledge economy will be one of the key pieces of this objective. It is also committed to local commerce, with the implantation of commercial basements in $90 \%$ of the project's buildings. MNNP is expected to generate 118,000 jobs during the urbanization and building works, to which another 130,000 will be added later because of the service activity in the new neighborhood.

Smart infrastructures (SDG 9): The Smart infrastructures are those using ICTs (Information Communication Technologies) for monitoring and control and for providing information to users [55]. MNNP has projected smart and innovative infrastructures, which will be supported by digital technology to apply the Smart City concept, which aims to optimize urban management and improve the quality of life of all citizens. The project encourages the development of intelligent transport in the area, which includes the new emerging models of urban mobility, which will be sustainable, electric, shared and autonomous.

Reduction of inequalities (SDG 10): The existing inequalities and vulnerabilities in our societies are related to the socioeconomic implications of climate change; thus, ethics demands social models that soften market forces and protect the most vulnerable [56]. 
Following this goal, MNNP incorporates this concept through inclusive urban planning. This means incorporating protected housing and residential land destined through public policies to support housing. The project will also provide the necessary public facilities to serve the northern area of Madrid, which are distributed over more than 250,000 $\mathrm{m}^{2}$. In this way, education, health, sports and cultural facilities will be within walking distance of the people who live and work in the area. Thanks to the participation of the citizens, the characteristics of the project have been adapted to the specific needs of the residents of the different districts, and of the city of Madrid in general.

Sustainable city and community (SDG 11): Economic growth needs to emphasize creativity and innovation to reinforce the environmental, social and cultural amenities of the city. This is an urgent priority for global sustainability that places the nexus between urban design and a community that participates and supports the future of the city [57]. Within this framework the project proposes a dense and compact urban model, with mixed urban uses. The great role of public transport, the extensive network of green areas and public free spaces have been planned for the well-being of people, making more efficient use of available resources to create a more sustainable city in all its aspects. The participation of the neighborhood community has been encouraged to involve the inhabitants in the design and responsible use of the spaces. With this purpose, Distrito Castellana Norte (DCN) has launched the new virtual platform VecinosMadridNorte.com with the aim of facilitating the participation of Madrid citizens in Madrid Nuevo Norte. Thanks to this new tool, the Social Engagement department will be able to continue informing in a much more accessible and easy way, expanding the interaction with all Madrid's neighbors and collecting their impressions online.

Responsible consumption (SDG 12): Consumers are increasingly demanding a more sustainable development from the different stakeholders. Taking advantage of this green conscience, it is essential that governments make decisions toward more sustainable possibilities, with adequate communication activities to motivate consumers to participate in a more responsible consumption [58]. With this objective, the project planning includes measures to reduce the consumption of resources. It is intended to minimize the consumption of water and energy and efficiently use construction materials. In this sense, both the responsible selection of materials necessary for urbanization and building works, as well as the reuse and recycling of existing materials are planned.

Fight against climate change (SDG 13): The present global climate emergency demands a transformation of our societies, which entails an important performance role in the adaptation and mitigation of climate change $[59,60]$. It is worth highlighting the function of the urban infrastructures of Madrid Nuevo Norte as a tool against climate change. Its urban infrastructures have been designed to enhance environmental values, sustainable mobility and the efficiency of the resources used in the urbanization and construction process.

Madrid Nuevo Norte's measures to deal with the climate emergency cover various areas, including the following:

- The naturalization of the urban environment to absorb carbon dioxide,

- The techniques for reducing the heat island effect with special vegetation,

- The inclusion of elements to provide shade in public spaces, improving thermal comfort,

- The public transport powered by renewable energies,

- The buildings that generate more energy than they consume.

Ecosystems and biodiversity (SDG 15): According to Pecl et al. [61], climate change is causing global geographical redistribution of plant and animal species. These distributional shifts are leading to new ecosystems and ecological communities, changes that will affect human society. For this specific issue MNNP has planned the creation of quality and lasting green spaces, such as the Central Park or the green axis, which will connect the north with the Monte del Pardo. It has also adopted measures to promote plant biodiversity with the use of species adapted to the climate and rainfall of Madrid. The project will serve as a green corridor between ecosystems, to link existing urban parks in the north of Madrid. 
The objective is twofold: preserve and respect the already consolidated environmental values, and create a new ecosystem that fosters biodiversity.

Partnerships to achieve sustainable goals (SDG 17): Nowadays, in the process of sustainable development, forming partnerships and encouraging overall cooperation make it easier to achieve the SDG [62]. For this reason, the urban regeneration project in the north of Madrid aims to be an example of public-private collaboration to achieve a responsible urban model. Several public administrations and private companies participated in the planning and execution of the project. Civil society has also mobilized in favor of the project, with the participation of more than 80 associations and groups from Madrid and more than 170,000 citizens.

\subsection{Madrid: A Benchmark for 2021 Urban Planning}

In MNNP, a new way of doing responsible urban planning has been promoted, integrating citizen participation to turn Madrid into an international benchmark [42]. The MNNP is planned around the regeneration of the Chamartín railway station. The use and modification of railway infrastructures is a common element to other similar projects, such as those recently carried out in Paris, London, Frankfurt and Milan. The planning of the Madrid urban project was developed around five basic axes: sustainability, social participation, integration of mixed urban uses, creation of state-of-the-art business centers and the prominence of public spaces through the integration and improvement of existing infrastructures and spaces [40].

Sustainability, as already mentioned in the previous section, focuses on four fundamental areas: water and sanitation management, use of non-polluting energy, creation of a sustainable urban environment, and climate action. However, apart from these four, the project applies another eight of the 17 sustainable development goals set by the UN.

Social participation is another essential feature of project planning. During the design phase, numerous consultations were made with residents of the affected areas to include their opinions in the final design. According to the promoters, people are the center of the project, a trend shared by the most avant-garde projects in the world. In the case of MNNP, it is the first time that the gender perspective was included in the design of a large urban project.

The integration and complementation of mixed urban uses refers to the combination and integration of homes, local shops, offices, and public facilities, mixing their uses and rationalizing mobility between them. It is the urban trend that is committed to creating dense and compact cities that improve the efficiency of available resources. The challenge is to combine accessibility, mobility and sustainability, applying the new Smart City concept. On the other hand, MNNP will create a state-of-the-art business center, which takes advantage of the proximity of a large city and the pre-existing infrastructures, among which the Chamartín Station and the Madrid Barajas Airport stand out.

Finally, the prominence of public spaces is also a critical aspect in the final design, since a large part of the surface will be allocated to spaces for public use, designed for social interaction and integrated with green and new surfaces and urban transport routes. The new public spaces will be created from the existing infrastructures and empty spaces, generating a large, cohesive and functional urban territory. It is a project with an inclusive will, which seeks the active coexistence of citizens, in which all people share quality public spaces. The concomitance of these five areas of action: sustainability, social participation, integration of mixed urban uses, creation of state-of-the-art business centers and prominence of public spaces makes Madrid Nuevo Norte a benchmark of avant-garde urbanism [63].

\section{Methodology, Sample and Data Collection}

For addressing the research objectives of the study, the quantitative approach was used. Questionnaires were handed out through the Internet to 122 professionals relevant to the urban development of Madrid. In particular, the sample included urban planners, architects, engineers, academics, project managers, sustainability consultants, real estate 
managers, etc. All participants were located in Madrid. Questionnaires were distributed mainly through social media along with a letter that explained the aims and the nature of the study. Initially, 200 questionnaires were sent; 122 valid responses were gathered, achieving a response rate of $61 \%$. The questionnaire was designed after the exploration of the relevant academic literature. All variables that were used in the research instrument were mentioned in previous studies (Table in Appendix A). The questionnaire included three sections. The first section concerned the demographic features of the participants in terms of gender, age, educational background and degree of involvement in the construction of MNNP and in mega projects in general. The second section measured the alignment of MNNP with the principles of sustainability. In this context, three sub-sections were included that measured the economic, environmental and social impact of the MNNP, respectively. The third section of the instrument measured the effect of MNNP in applying city marketing strategies. A seven-point Likert scale was used as a response format for all questions, with 1 signifying strongly disagree and 7 representing strongly agree. Relevant to the design of the questionnaire, the two main research questions of the current study were

- $\quad$ Research Question 1:

Is MNNP aligned with the criteria of sustainability (economic, environmental and social)?

- $\quad$ Research Question 2:

Does MNNP contribute to the implementation of sustainable city marketing strategies in the region of Madrid?

Firstly, descriptive measures were used since they comprised the fundamental building blocks of data analysis. They provided insights into the data and assisted in the interpretation of the results $[64,65]$. Secondly, four exploratory factor analyses (EFAs) were employed using the varimax rotation and the principal component approach. The EFAs concerned measurement of the economic, environmental and social impact of MNNP, aiming to detect the key determinants of the association between MNNP and sustainability. The fourth EFA concerned the grouping of city marketing strategies, facilitating the final step of the analysis. Thirdly, regression analysis was employed with the key constructs that were identified through the EFAs. Multiple regression with ordinary least squares was used. Several models were employed in which variables were entered gradually for obtaining the most satisfactory results. The dependent variables in the regression analyses were three: (1) MNNP success, (2) implementation of city marketing strategies that contribute in economic development, and (3) city marketing strategies that concern local governance. The mathematical form of the models is illustrated below:

$$
Y=\beta o+\beta 1 X+\beta 2 X+\beta 3 X+\beta 4 X+e 1
$$

where:

$\mathrm{Y}=$ the dependent variables: (a) MNNP success, (b) implementation of city marketing strategies that contribute in economic development, and (c) city marketing strategies that concern local governance.

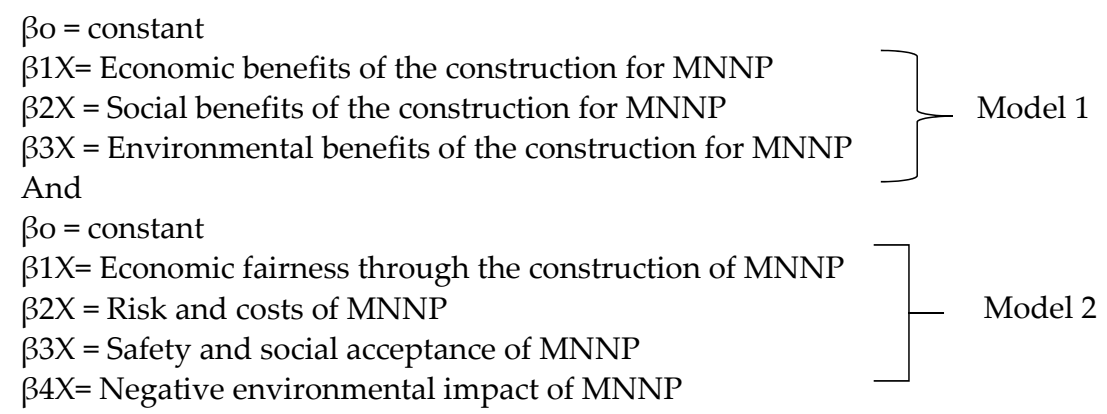

Model 2

Additionally, a third model was employed where the dependent variable was MNNP success and the independent variables were: implementation of city marketing strategies 
that contribute to economic development, and city marketing strategies that concern local governance.

\section{Data Analysis}

\subsection{Demographics}

Most of the participants were men (68.9\%), 30-49 years old (66.4\%) and well educated (Table 1). Indicatively, $60.7 \%$ of the respondents held a Master's Degree, while $27.9 \%$ had also a PhD. The degree of involvement of participants in MNNP was low (mean: 2.29), which was desirable for avoiding response error. Lastly, the level of experience of informants in participating in similar large infrastructure projects was higher (mean: 4.45).

Table 1. Sample demographics.

\begin{tabular}{|c|c|c|}
\hline Variable & $\mathbf{N}$ & $\%$ \\
\hline \multicolumn{3}{|l|}{ Gender } \\
\hline Male & 84 & 68.9 \\
\hline Female & 38 & 31.1 \\
\hline Total & 122 & 100.0 \\
\hline \multicolumn{3}{|l|}{ Age } \\
\hline $18-29$ & 9 & 7.4 \\
\hline $30-39$ & 34 & 27.9 \\
\hline $40-49$ & 47 & 38.5 \\
\hline $50-59$ & 25 & 20.5 \\
\hline $60+$ & 7 & 5.7 \\
\hline Total & 122 & 100.0 \\
\hline \multicolumn{3}{|l|}{ Educational level } \\
\hline University/College & 14 & 11.5 \\
\hline Master & 74 & 60.7 \\
\hline $\mathrm{PhD}$ & 34 & 27.9 \\
\hline Total & 122 & 100.0 \\
\hline Experience and Involvement & Mean & \\
\hline Degree of involvement in MNNP & 2.29 & \\
\hline Level of experience in participating in large infrastructure projects & 4.45 & \\
\hline$(1=$ Not at all, $7=$ to a great extent $)$ & & \\
\hline
\end{tabular}

\subsection{Descriptive Measures}

\section{- Economic impact}

Firstly, the analysis revealed that MNNP will have an overall positive economic outcome in the region of Madrid. In particular, it is expected that MNNP will attract investments, provide opportunities for local firms, enhance local employment and increase revenues for local government authorities. The effect on tourism is also expected to be positive. Concerns regarding the costs and the associated risks of the MNNP fluctuated in moderate levels, revealing the positive stances of urban planners toward MNNP. However, the effect of MNNP on eliminating economic inequalities is milder.

- Environmental Impact

MNNP is expected also to have a positive environmental impact on the city of Madrid. This is reflected mainly in the provision of sufficient open and green spaces, as well as in the application of green practices during the construction process. Nevertheless, MNNP is expected to cause air and noise pollution, whereas the effects on ground and water are considered as less adverse. 


\section{- Social impact}

The positive social impact of MNNP is reflected in three facts. Firstly, as a mega project it will provide basic civic facilities, improving the quality of life of local residents. Secondly, MNNP will improve transportation efficiency and mobility in Madrid, enabling walking and biking. Thirdly, MNNP will ensure safety for workers and for end-users. Furthermore, the visual impact of the mega project is expected to be notable. Finally, urban planners support that MNNP has the overall acceptance of the Community of Madrid, a factor that has vital importance for its overall success. On the other hand, MNNP fails in representing the local cultural and historical heritage of the Spanish capital.

\section{- $\quad$ MNNP Success}

Concerns were expressed regarding the time schedule and the budget of MNNP. It is expected that the construction of the project will last a long time, as well as that it will require more funds to be completed. However, final users will be satisfied with MNNP. Technical professionals and local authorities are considered to be capable of completing and managing MNNP, although, the ability of the engineers exceeds the capacity of local governors. It is notable that in most South European Countries there is a skepticism regarding the efficiency of local authorities.

- City marketing strategies

Overall, the research showed that MNNP will facilitate and accelerate the implementation of city marketing strategies. Most of these strategies concern the economic development of Madrid (attraction of foreign investments and European funds, creation of a favorable business climate, enhanced competitiveness of the city, etc.). Additionally, there are a number of practices that are relevant to spatial and urban management issues (urban regeneration, improvement of the green infrastructures of the city, regeneration of existing secondary centers, etc.), revealing the multidimensional role of MNNP. Lastly, MNNP is expected to assist in the implementation of tourism marketing strategies.

\subsection{Exploratory Factor Analyses (EFAs)}

Firstly, the EFA that concerned the economic dimensions of MNNP comprised three constructs: F1: Local economic benefits; F2: Risks, costs; and F3: Economic fairness. As shown in Table 2, seven factors were loaded in F1, five factors were loaded in F2 and three factors were loaded in F3. Cronbach's alpha in all cases was larger than 0.7, revealing scale reliability and inner consistency of each construct $[64,65]$. The Kaiser-Meyer-Olkin (KMO) measure was 0.858 , and Bartlett's Test of Sphericity was statistically significant at 0.000 level, indicating the appropriateness of the factor analysis $[65,66]$.

Moreover, the EFA that concerned the environmental dimensions of MNNP revealed two latent factors: F1: Environmental benefits and F2: Pollution (Table 3). F1 included eight factors and F2 involved four aspects that concerned the type of environmental pollution caused by the construction of MNNP. In this case, Cronbach's alpha was even higher, more than 0.9 in both constructs, indicating measurement reliability and consistency. KMO value was 0.895 , and Bartlett's Test of Sphericity was statistically significant at 0.000 level, revealing that the data were suitable for the certain type of analysis. It is also notable that all factor loadings were above 0.58 .

The EFA that was relevant to the social dimensions of MNNP also revealed two latent constructs: F1: Social benefits and F2: Safety and social acceptance. Eight factors were loaded in social benefits (Cronbach's alpha: 0.914) and four factors in safety and social acceptance (Cronbach's alpha: 0.705). KMO value was 0.896 and Bartlett's Test of Sphericity was statistically significant at 0.000 level. All factor loadings were above 0.49 (Table 4). 
Table 2. EFA-Economic factors.

\begin{tabular}{|c|c|c|c|}
\hline Construct & Items & $\begin{array}{l}\text { Factor } \\
\text { Loadings }\end{array}$ & $\begin{array}{l}\text { Cronbach's } \\
\text { alpha }\end{array}$ \\
\hline \multirow[t]{7}{*}{ F1: Local Economic Benefits } & \multirow{2}{*}{$\begin{array}{l}\text { MNNP will have a positive impact on local employment. } \\
\text { MNNP will have a positive impact on tourism development } \\
\text { of Madrid. }\end{array}$} & 0.743 & \multirow[t]{7}{*}{0.873} \\
\hline & & 0.674 & \\
\hline & $\begin{array}{c}\text { MNNP will cause a significant increase in nearby property } \\
\text { values. }\end{array}$ & 0.741 & \\
\hline & MNNP will provide opportunities to local businesses. & 0.555 & \\
\hline & $\begin{array}{c}\text { MNNP will contribute to the local economic development } \\
\text { of Madrid. }\end{array}$ & 0.660 & \\
\hline & MNNP will have economic benefits for local government. & 0.565 & \\
\hline & $\begin{array}{l}\text { MNNP will encourage businesses to make investments in } \\
\text { the area }\end{array}$ & 0.774 & \\
\hline \multirow[t]{5}{*}{ F2: Risks and Costs } & I consider the cost of construction of MNNP as high. & 0.635 & \multirow[t]{5}{*}{0.836} \\
\hline & $\begin{array}{c}\text { There is a high financial risk in the construction of MNNP } \\
\text { due to the recent economic recession. }\end{array}$ & 0.812 & \\
\hline & $\begin{array}{c}\text { There is a high economic risk in the construction of MNNP } \\
\text { due to the pandemic (COVID-19). }\end{array}$ & 0.829 & \\
\hline & MNNP will have high maintenance cost. & 0.755 & \\
\hline & MNNP will increase the cost of living in Madrid. & 0.673 & \\
\hline \multirow[t]{3}{*}{ F3: Economic Fairness } & $\begin{array}{c}\text { The procedures for carrying out MNNP are done in a } \\
\text { transparent manner. }\end{array}$ & 0.500 & \multirow[t]{3}{*}{0.747} \\
\hline & $\begin{array}{l}\text { The prices of the houses for residents in MNNP will be } \\
\text { affordable. }\end{array}$ & 0.824 & \\
\hline & $\begin{array}{l}\text { MNNP will contribute to the fair distribution of wealth for } \\
\text { the citizens of Madrid. }\end{array}$ & 0.800 & \\
\hline Kaiser-Meyer-Olkin & 0.858 & & \\
\hline Bartlett's Test of Sphericity (Sig.) & 0.000 & & \\
\hline
\end{tabular}

Table 3. EFA-Environmental factors.

\begin{tabular}{|c|c|c|c|}
\hline Construct & Items & Factor Loadings & Cronbach's alpha \\
\hline \multirow[t]{8}{*}{ F1: Environmental Benefits } & MNNP promotes efficient urban land usage. & 0.582 & 0.913 \\
\hline & MNNP will contribute to energy saving. & 0.705 & \\
\hline & MNNP promotes usage of green energy. & 0.822 & \\
\hline & $\begin{array}{l}\text { MNNP will provide sufficient public open } \\
\text { spaces. }\end{array}$ & 0.776 & \\
\hline & $\begin{array}{l}\text { MNNP will provide sufficient green spaces } \\
\text { (trees, flora, and fauna in neighborhood). }\end{array}$ & 0.711 & \\
\hline & $\begin{array}{c}\text { In MNNP, green building practices throughout } \\
\text { the design and construction processes will be } \\
\text { applied. }\end{array}$ & 0.811 & \\
\hline & $\begin{array}{l}\text { MNNP will preserve the local character (such as } \\
\text { natural landscape) and natural resources during } \\
\text { construction. }\end{array}$ & 0.610 & \\
\hline & $\begin{array}{l}\text { MNNP is harmonized with the local natural } \\
\text { setting and with surroundings. }\end{array}$ & 0.587 & \\
\hline \multirow{4}{*}{$\begin{array}{c}\text { F2: Environmental Pollution } \\
\text { (Negative Impact) }\end{array}$} & MNNP will cause water pollution. & 0.803 & 0.944 \\
\hline & MNNP will cause noise pollution. & 0.908 & \\
\hline & MNNP will cause air pollution. & 0.904 & \\
\hline & MNNP will cause ground pollution. & 0.883 & \\
\hline Kaiser-Meyer-Olkin & 0.895 & & \\
\hline artlett's Test of Sphericity (Sig.) & 0.000 & & \\
\hline
\end{tabular}


Table 4. EFA-Social factors.

\begin{tabular}{|c|c|c|c|}
\hline Construct & Items & Factor Loadings & Cronbach A \\
\hline \multirow[t]{9}{*}{ F1: Social Benefits } & $\begin{array}{l}\text { MNNP is designed in a way that represents the local } \\
\text { cultural and historical heritage of Madrid. }\end{array}$ & 0.723 & 0.914 \\
\hline & $\begin{array}{c}\text { The aesthetic quality (visual impact) of MNNP will } \\
\text { be high. }\end{array}$ & 0.496 & \\
\hline & MNNP will reduce traffic problems in Madrid. & 0.781 & \\
\hline & $\begin{array}{l}\text { MNNP will have a positive impact on the quality of } \\
\text { living of the citizens of Madrid. }\end{array}$ & 0.853 & \\
\hline & $\begin{array}{l}\text { MNNP is aligned with resilient planning enabling } \\
\text { future expansions due to population growth. }\end{array}$ & 0.857 & \\
\hline & MNNP will expand mobility and transportation. & 0.634 & \\
\hline & $\begin{array}{l}\text { MNNP will provide basic services and civic facilities } \\
\text { (banks, hospitals, parks). }\end{array}$ & 0.618 & \\
\hline & $\begin{array}{c}\text { MNNP will improve proximity to jobs for the } \\
\text { residents. }\end{array}$ & 0.841 & \\
\hline & MNNP will enable walking and biking. & 0.811 & \\
\hline \multirow[t]{4}{*}{ F2: Safety And Social Acceptance } & $\begin{array}{l}\text { Health and safety of the workers will be ensured } \\
\text { during the construction of MNNP. }\end{array}$ & 0.657 & 0.705 \\
\hline & $\begin{array}{l}\text { The Community of Madrid is involved in the design } \\
\text { and the construction of MNNP. }\end{array}$ & 0.602 & \\
\hline & $\begin{array}{c}\text { There is public acceptance toward the project of } \\
\text { MNNP in Madrid. }\end{array}$ & 0.516 & \\
\hline & $\begin{array}{l}\text { MNNP will ensure security within buildings to } \\
\text { end-users. }\end{array}$ & 0.580 & \\
\hline Kaiser-Meyer-Olkin & 0.896 & & \\
\hline Bartlett's Test of Sphericity (Sig.) & 0.000 & & \\
\hline
\end{tabular}

The fourth EFA indicated that city marketing strategies could be distinguished in two categories: F1: Economic development strategies and F2: Local governance strategies. In this case, F1 included eight subfactors and F2 included seven subfactors. KMO value was 0.937 and Bartlett's Test of Sphericity was statistically significant at 0.000 level, indicating the appropriateness of factor analysis. Cronbach's alpha was relatively high in both constructs ( 0.950 and 0.929 , respectively) and all factor loadings ranged from 0.59 to 0.872 . As stated by He et al. [67], such results further validated the rationality of classifying city marketing strategies according to these two proposed constructs (Table 5).

Finally, the construct MNNP success was generated by computing five Likert-scale items, namely: Ability of engineers and technical professionals to perform the mega project, Satisfaction of the community with MNNP; Local authorities' capacity in managing MNNP; Meeting expected objectives; and Completion of the project according to timeline. The reliability value of MNNP success was 0.817 .

Table 6 summarizes the results of the four EFAs that were presented before. As shown below, MNNP seems to be aligned with the principles of sustainability since it incorporates economic, environmental and social benefits. However, risks, costs, pollution, social acceptance and economic fairness should be taken into consideration for improving the overall outcome of the project. MNNP is also a vehicle for applying city marketing strategies. Local authorities can play a substantial role in designing and applying these strategies, aiming mainly at boosting economic development in the region of Madrid. 
Table 5. EFA—City marketing strategies

\begin{tabular}{|c|c|c|c|}
\hline Construct & Items & Factor Loadings & Cronbach A \\
\hline \multirow[t]{8}{*}{$\begin{array}{c}\text { F1: Economic Development } \\
\text { strategies }\end{array}$} & $\begin{array}{c}\text { MNNP will contribute to the urban regeneration of } \\
\text { Madrid. }\end{array}$ & 0.779 & 0.950 \\
\hline & $\begin{array}{l}\text { MNNP will contribute to the development of the } \\
\text { human capital of Madrid. }\end{array}$ & 0.759 & \\
\hline & $\begin{array}{c}\text { MNNP will enhance the competitiveness of Madrid } \\
\text { on an international basis. }\end{array}$ & 0.872 & \\
\hline & MNNP will create a favorable business climate. & 0.708 & \\
\hline & $\begin{array}{l}\text { MNNP will assist the city of Madrid to attract } \\
\text { foreign investments and European funds. }\end{array}$ & 0.848 & \\
\hline & $\begin{array}{l}\text { MNNP will facilitate the operation of Small and } \\
\text { Medium-sized Enterprises (SMEs). }\end{array}$ & 0.590 & \\
\hline & $\begin{array}{c}\text { MNNP will enhance the level of visitor satisfaction } \\
\text { with the city of Madrid }\end{array}$ & 0.669 & \\
\hline & $\begin{array}{c}\text { MNNP will result in increased revenues from } \\
\text { tourism arrivals. }\end{array}$ & 0.623 & \\
\hline \multirow[t]{8}{*}{ F2: Local governance strategies } & $\begin{array}{c}\text { MNNP will assist authorities in Madrid to create } \\
\text { networks with other cities. }\end{array}$ & 0.660 & 0.929 \\
\hline & MNNP will accelerate institutional & & \\
\hline & $\begin{array}{l}\text { collaboration/cooperation among levels of } \\
\text { government and between public and private actors. }\end{array}$ & 0.607 & \\
\hline & $\begin{array}{l}\text { MNNP will improve the quality of social services } \\
\text { (healthcare, education, social assistance). }\end{array}$ & 0.654 & \\
\hline & $\begin{array}{l}\text { MNNP will promote the cultural heritage and the } \\
\text { historicity of the city. }\end{array}$ & 0.842 & \\
\hline & $\begin{array}{l}\text { MNNP will help authorities to identify zones for } \\
\text { different spatial policies. }\end{array}$ & 0.815 & \\
\hline & $\begin{array}{c}\text { MNNP will assist local authorities to organize more } \\
\text { cultural events and activities. }\end{array}$ & 0.751 & \\
\hline & $\begin{array}{l}\text { MNNP will enhance the overall efficiency of the } \\
\text { means of transport in the city of Madrid. }\end{array}$ & 0.709 & \\
\hline Kaiser-Meyer-Olkin & 0.937 & & \\
\hline Bartlett's Test of Sphericity (Sig.) & 0.000 & & \\
\hline
\end{tabular}

Table 6. A summary of EFAs.

\begin{tabular}{ccc}
\hline Economic Dimensions & Environmental Dimensions & Social Dimensions \\
\hline F1: Local economic benefits & F1: Environmental benefits & F1: Social benefits \\
F2: Risks and costs & F2: Environmental pollution (-) & F2: Safety and social acceptance \\
F3: Economic fairness & & F2: Local governance strategies \\
\hline
\end{tabular}

\subsection{Regressions}

Three regression models were employed where the dependent variable was MNNP success. In the first model, we regressed MNNP success with the benefits of sustainability, namely, economic, social and environmental benefits. As shown in Table 7, economic and social benefits are significant predictors of MNNP success, whereas environmental benefits are not. The ties with social benefits seemed to be stronger. The second model indicated that safety and social acceptance of the mega project and the negative environmental impact of MNNP also influenced its success. Obviously, $\beta$ coefficient $(-0.261)$ revealed that the pollution caused by MNNP had a negative impact on its performance. No significant associations were identified with economic fairness and risks and costs. Lastly, MNNP success was associated only with the implementation of city marketing strategies that are focused in economic growth. No significance was identified with local governance strategies. In all models, $\mathrm{R}$ square values were relatively high, signifying the overall 
significance of the prediction models. All variance inflation factor (VIF) values were below 5 , indicating that multicollinearity was not a problem of the current analysis $[67,68]$.

Two prediction models were employed where the dependent variable was city marketing approaches and, more specifically, economic development strategies (Table 8). The analysis showed that economic and social benefits of MNNP, economic fairness, safety and social acceptance and negative environmental impact are significant predictors of the efficient application of economic development strategies in the city marketing context. The same also stands for the application of local governance strategies. However, local governance city marketing approaches are associated also with the environmental benefits of MNNP. In short, MNNP can play a vital role in implementing city marketing strategies. Nevertheless, these practices should be aligned with sustainability criteria. Again, in all the aforementioned models R square values were high. Moreover, VIF was lower than 5, signifying no multicollinearity.

Table 7. Regression analysis (MNNP success determinants).

\begin{tabular}{|c|c|c|c|c|c|c|}
\hline \multicolumn{7}{|c|}{ Dependent Variable: MNNP Success } \\
\hline & $\begin{array}{c}\text { Standardized } \\
\beta\end{array}$ & Sig & VIF & $\mathrm{F}$ & $R^{2}$ & Overall Sig \\
\hline Model 1 & & & & 39,823 & 0.503 & 0.000 \\
\hline (Constant) & & 0.091 & & & & \\
\hline Economic benefits & 0.186 ** & 0.041 & 1919 & & & \\
\hline Social benefits & $0.446^{* *}$ & 0.001 & 4359 & & & \\
\hline $\begin{array}{l}\text { Environmental } \\
\text { benefits }\end{array}$ & 0.138 & 0.273 & 3699 & & & \\
\hline Model 2 & & & & 38,456 & 0.568 & 0.000 \\
\hline (Constant) & & 0.000 & & & & \\
\hline Economic fairness & 0.073 & 0.359 & 1721 & & & \\
\hline Risks and costs & -0.140 & 0.064 & 1524 & & & \\
\hline Safety and social acceptance & $0.484 * *$ & 0.000 & 1498 & & & \\
\hline Negative environmental impact & $-0.261^{* *}$ & 0.001 & 1688 & & & \\
\hline Model 3 & & & & 44,858 & 0.430 & 0.000 \\
\hline (Constant) & & 0.000 & & & & \\
\hline Local governance strategies & 0.210 & 0.126 & 3854 & & & \\
\hline Economic development strategies & $0.467^{* *}$ & 0.001 & 3854 & & & \\
\hline
\end{tabular}

Statistically significant standardized coefficients at ${ }^{* *} p<0.01$.

Table 8. Regression analysis (City marketing strategies).

\begin{tabular}{|c|c|c|c|c|c|c|}
\hline \multicolumn{7}{|c|}{ Dependent Variable: Economic Development Strategies } \\
\hline & $\begin{array}{l}\text { Standardized } \\
\beta\end{array}$ & Sig & VIF & $\mathrm{F}$ & $R^{2}$ & Overall Sig. \\
\hline Model 1 & & م040 & & 150,523 & 0.793 & 0.000 \\
\hline Economic benefits & $0.376^{* *}$ & $\begin{array}{l}0.049 \\
0.000\end{array}$ & 1919 & & & \\
\hline Social benefits & $0.564^{* *}$ & 0.000 & 4359 & & & \\
\hline $\begin{array}{l}\text { Environmental } \\
\text { benefits }\end{array}$ & 0.029 & 0.719 & 3699 & & & \\
\hline Model 2 & & & & 55,693 & 0.656 & 0.000 \\
\hline (Constant) & & 0.000 & & & & \\
\hline Economic fairness & $0.332 * *$ & 0.000 & 1721 & & & \\
\hline Risks and costs & -0.124 & 0.067 & 1524 & & & \\
\hline Safety and social acceptance & $0.370^{* *}$ & 0.000 & 1498 & & & \\
\hline Negative environmental impact & $-0.209^{* *}$ & 0.004 & 1688 & & & \\
\hline $\begin{array}{l}\text { Dependent variable: Local } \\
\text { governance strategies }\end{array}$ & & & & & & $\begin{array}{l}\text { Dependent variable: Local } \\
\text { governance strategies }\end{array}$ \\
\hline
\end{tabular}


Table 8. Cont.

\begin{tabular}{|c|c|c|c|c|c|c|}
\hline \multicolumn{7}{|c|}{ Dependent Variable: Economic Development Strategies } \\
\hline & $\begin{array}{l}\text { Standardized } \\
\beta\end{array}$ & Sig & VIF & F & $R^{2}$ & \\
\hline Model 1 & & & & 124,775 & 0.760 & Model 1 \\
\hline (Constant) & & 0.071 & & & & (Constant) \\
\hline Economic benefits & $0.146^{* *}$ & 0.021 & 1919 & & & Economic benefits \\
\hline Social benefits & $0.556^{* *}$ & 0.000 & 4359 & & & Social benefits \\
\hline $\begin{array}{c}\text { Environmental } \\
\text { benefits }\end{array}$ & $0.233^{* *}$ & 0.008 & 3699 & & & $\begin{array}{l}\text { Environmental } \\
\text { benefits }\end{array}$ \\
\hline Model 2 & & & & 43,869 & 0.600 & Model 2 \\
\hline (Constant) & & 0.000 & & & & (Constant) \\
\hline Economic fairness & $0.337^{* *}$ & 0.000 & 1721 & & & Economic fairness \\
\hline Risks and costs & -0.073 & 0.312 & 1524 & & & Risks and costs \\
\hline Safety and social acceptance & $0.309 * *$ & 0.000 & 1498 & & & Safety and social acceptance \\
\hline Negative environmental impact & $-0.264^{* *}$ & 0.001 & 1688 & & & Negative environmental impact \\
\hline
\end{tabular}

\section{Answering Research Questions}

\subsection{Is MNNP Aligned with the Criteria of Sustainability (Economic, Environmental and Social)?}

Firstly, it was found that MNNP overall meets the criteria of sustainable development. More specifically, the project is expected to contribute to the local economic development of Madrid, as well as provide social benefits such as provision of basic civil facilities, positive visual impact, enhanced transportation efficiency and mobility, etc. For all these reasons MNNP has the acceptance of the local society. Furthermore, the environmental outcome of MNNP is also expected to be positive, since it will provide sufficient open and green spaces, whereas the pollution that will be caused during the construction process is expected to be at controllable levels. On the other hand, key limitations of the MNNP involve the inability to eliminate social inequalities and to harmonize with the cultural and historical heritage of the Spanish capital. In addition, concerns were identified regarding the budget and the timeline of the project. In sum, urban planners and professionals illustrated positive stances and attitudes toward the effects of MNNP on the city of Madrid. It seems that this mega project will upgrade overall the quality of life in the Spanish capital, succeeding in addressing the needs of modern urban centers.

However, the success of MNNP is highly dependent on meeting key sustainability criteria. In particular, MNNP performance is associated with economic and social benefits, economic fairness, safety issues and social acceptance. These criteria were also mentioned in previous studies by several authors [69-75]. It seems that mega projects, to be successful, should take into consideration several sustainability dimensions, highlighting the crucial role that the philosophy of sustainable development plays in urban regeneration and planning. It is notable that no association was found between MNNP success and the environmental benefits of MNNP, revealing that the there is room for further improvement of the environmental outcome of MNNP. Social acceptance and elimination of inequalities are also critical points that the constructors of MNNP should emphasize to improve the overall performance of the project.

\subsection{Does MNNP Contribute to the Implementation of Sustainable City Marketing Strategies in the Region of Madrid?}

The research also showed that MNNP is an efficient vehicle for the implementation of city marketing strategies. City marketing practices that are applicable in the case of MNNP can be distinguished in strategies that concern the economic development of Madrid and local governance strategies. It is indicative that these strategies are also aligned with sustainability principles. More specifically, city marketing strategies address the following 
sustainability criteria: economic, social and environmental benefits; economic fairness; safety and social acceptance. Therefore, MNNP provides significant opportunities to local authorities to implement sustainable city marketing strategies, aiming to improve the competitiveness and the quality of life in the city of Madrid. It seems that big infrastructure projects can substantially enhance urban sustainability through the application of city marketing strategies. Nevertheless, city marketing should be focused on meeting key urban sustainability dimensions mentioned in the literature, such as: environmental protection and restoration, quality of life in the community, usage of natural resources, mobility and sustainable transportation, safety, preservation of public space, cultural and natural heritage, etc. [8-11].

\section{Conclusions}

MNNP (Madrid New North) is an urban redevelopment program applied in the city of Madrid in Spain. Relevant to this, the aim of this project was twofold: firstly, it was investigated if MNNP is aligned with the principles of sustainability. Secondly, the paper examined the impact of MNNP on the application of city marketing strategies in Madrid. The research showed that overall, Nuevo Norte contributes to the sustainable development of Madrid. Moreover, it provides significant opportunities to local authorities for implementing sustainable city marketing strategies, aiming to improve the competitiveness and the quality of life in the Spanish capital. To this end, it seems that city marketing, through the construction of mega projects, should incorporate sustainability, ensuring a better life for local residents and communities in general. The research is expected to assist local authorities in Spain to harness the potential of mega projects, such as Nuevo Norte, in designing city marketing strategies and to promote Madrid in an international context as a city that emphasizes urban sustainability.

Author Contributions: Conceptualization: T.M., Methodology: G.G., Formal analysis: L.J. and G.G., Investigation: T.M. and L.J., Data preparation: L.J. and G.G., Writing-original draft preparation: T.M., L.J. and G.G., Supervision: T.M., Project administration: T.M., Writing, review and editing: T.M. All authors have read and agreed to the published version of the manuscript.

Funding: This research received no external funding.

Institutional Review Board Statement: Not applicable.

Informed Consent Statement: Not applicable.

Data Availability Statement: Data derived from empirical research contacted by the authors.

Acknowledgments: Many thanks to all experts that participate on this study.

Conflicts of Interest: The authors declare no conflict of interest.

\section{Appendix A}

Questionnaire Items and Sources

\begin{tabular}{|c|c|}
\hline Economic Factors & Source: \\
\hline 1. The procedures for carrying out Nuevo Norte are done in a transparent manner. & {$[67,75]$} \\
\hline 2. Nuevo Norte will have a positive impact on local employment. & [69-74] \\
\hline 3. Nuevo Norte will have a positive impact on tourism development of Madrid. & [69] \\
\hline 4. I consider the cost of construction of Nuevo Norte as high. & [69] \\
\hline 5. Nuevo Norte will cause a significant increase in land value in Madrid. & [71] \\
\hline 6. Nuevo Norte will cause a significant increase in nearby property values. & [71] \\
\hline 7. Nuevo Norte will provide opportunities to local businesses. & {$[71,74]$} \\
\hline 8. There is a high financial risk in the construction of Nuevo Norte due to the recent economic recession. & {$[71,76]$} \\
\hline 9. There is a high economic risk in the construction of Nuevo Norte due to the pandemic (COVID-19). & - \\
\hline
\end{tabular}




\begin{tabular}{|c|c|}
\hline Economic Factors & Source: \\
\hline 10. Nuevo Norte will have high maintenance cost. & [70] \\
\hline 11. The prices of the houses for residents in Nuevo Norte will be affordable. & {$[70,72]$} \\
\hline 12. Nuevo Norte will contribute to the local economic development of Madrid. & {$[72]$} \\
\hline 13. Nuevo Norte will contribute to the fair distribution of wealth for the citizens of Madrid. & {$[72,74]$} \\
\hline 14. Nuevo Norte will increase the cost of living in Madrid. & {$[72]$} \\
\hline 15. Nuevo Norte will have economic benefits for local government. & [73] \\
\hline 16. Nuevo Norte will encourage businesses to make investments in the area. & [74] \\
\hline \multicolumn{2}{|l|}{ Environmental factors } \\
\hline 17. Nuevo Norte will cause water pollution. & {$[69,71-75]$} \\
\hline 18. Nuevo Norte will cause noise pollution. & {$[69,71-75]$} \\
\hline 19. Nuevo Norte will cause air pollution. & {$[72-74]$} \\
\hline 20. Nuevo Norte will cause ground pollution. & {$[71,72,74]$} \\
\hline 21. Nuevo Norte promotes efficient urban land usage. & {$[71,72]$} \\
\hline 22. Nuevo Norte, as a mega project, addresses climate change problems. & {$[71,72]$} \\
\hline 23. Nuevo Norte will contribute to energy saving. & {$[70,72]$} \\
\hline 24. Nuevo Norte promotes usage of green energy. & {$[70]$} \\
\hline 25. Nuevo Norte will provide sufficient public open spaces. & {$[69,71,73]$} \\
\hline 26. Nuevo Norte will provide sufficient green spaces (trees, flora, and fauna in neighborhood). & {$[70-74]$} \\
\hline 27. In the Nuevo Norte project, green building practices throughout the design and construction processes will be applied. & {$[73,74]$} \\
\hline 28. Nuevo Norte will preserve the local character (such as natural landscape) and natural resources during construction. & {$[71,74]$} \\
\hline 29. Nuevo Norte is harmonized with the local natural setting and with the surroundings. & {$[69,73]$} \\
\hline \multicolumn{2}{|l|}{ Social factors } \\
\hline 30. Nuevo Norte is designed in a way that represents the local cultural and historical heritage of Madrid. & {$[69,72-74]$} \\
\hline 31. Health and safety of the workers will be ensured during the construction of Nuevo Norte. & {$[69,71,72,74]$} \\
\hline 32. The Community of Madrid is involved in the design and the construction of Nuevo Norte. & {$[70,71]$} \\
\hline 33. There is public acceptance of the project of Nuevo Norte in Madrid. & [75] \\
\hline 34. Nuevo Norte will ensure safety for pedestrian and public transport users. & {$[58,60]$} \\
\hline 35. The aesthetic quality (visual impact) of Nuevo Norte will be high. & {$[71,73,74]$} \\
\hline 36. Nuevo Norte will reduce traffic problems in Madrid. & {$[71,74]$} \\
\hline 37. Nuevo Norte will have a positive impact on the quality of living of the citizens of Madrid. & {$[70,72,77]$} \\
\hline 38. Nuevo Norte will reduce social inequity by enabling residents from a wide range of economic levels to live in one community. & {$[70,72,74]$} \\
\hline 39. Nuevo Norte will ensure security within buildings to end-users. & {$[70,72,74]$} \\
\hline 40. Nuevo Norte is aligned with resilient planning, enabling future expansions due to population growth. & [74] \\
\hline 41. Nuevo Norte will expand mobility and transportation. & [74] \\
\hline 42. Nuevo Norte will provide basic services and civic facilities (banks, hospitals, parks). & [74] \\
\hline 43. Nuevo Norte will improve proximity to jobs for the residents. & [74] \\
\hline 44. Nuevo Norte will enable walking and biking. & [74] \\
\hline 45. Nuevo Norte involves high social risk (involvement of too many multi-level decision-making bodies). & [76] \\
\hline
\end{tabular}

$$
\text { Other critical factors- NN success }
$$

46. Project engineers and technical professionals have the ability to effectively execute Nuevo Norte.

47. Local authorities in Madrid have the ability to effectively manage Nuevo Norte.

[77]

$[73,77]$

[77]

48. Nuevo Norte will be completed on schedule.

49. The construction of Nuevo Norte will last a long time.

50. Nuevo Norte will be completed within budget.

51. The results or deliverables of Nuevo Norte will meet the expected objectives.

$[71,76]$

$[67,77]$

[77]

$[71,73]$

\section{Nuevo Norte and City marketing}

Source:

1. Nuevo Norte will assist authorities in Madrid to create networks with other cities.

2. The construction of Nuevo Norte signifies that Madrid has efficient urban governance.

3. Nuevo Norte will contribute to the urban regeneration of Madrid.

4. Nuevo Norte will contribute to the development of the human capital of Madrid.

5. Nuevo Norte will improve the green infrastructures of Madrid.

6. Nuevo Norte will enhance the competitiveness of Madrid on an international basis.

7. Nuevo Notre will accelerate institutional collaboration/cooperation among levels of government and between public and private actors.

8. Nuevo Norte will create a favorable business climate.

[78-80]

$[81,82]$

$[80,83,84]$

$[85,86]$

$[82,85,87]$

9. Nuevo Norte will improve the quality of social services (healthcare, education, social assistance). 
15. Nuevo Norte will facilitate the operation of Small and Medium-sized Enterprises (SMEs).

\section{References}

1. Deffner, A.; Liouris, C. City Marketing: A significant planning tool for urban sustainable development in a globalised economy. In Proceedings of the 45th Congress of the European Regional Science Association: "Land Use and Water Management in a Sus-tainable Network Society", Amsterdam, The Netherlands, 23-27 August 2005.

2. Deffner, A.; Karachalis, N.; Psatha, E.; Metaxas, T.; Sirakoulis, K. City marketing and planning in two Greek cities: Plurality or constraints? Eur. Plan. Stud. 2019, 28, 1333-1354. [CrossRef]

3. Boisen, M.; Terlouw, K.; Groote, P.; Couwenberg, O. Reframing place promotion, place marketing, and place branding - moving beyond conceptual confusion. Cities 2018, 80,4-11. [CrossRef]

4. Kennedy, L.; Robbins, G.; Bon, B.; Takano, G.; Varrel, A.; Andrade, J. Megaprojects and Urban Development in Cities of the South. Available online: http://chance2sustain.eu/fileadmin/Website/Dokumente/Dokumente/Publications/publications_2014/C2S_ TR_No05_WP2_-_Megaprojects_and_Urban_Development_in_Cities_of_the_South_V2-3.pdf (accessed on 12 November 2020).

5. Mylonas, C.; Xenidis, Y. Megaproject development in the context of sustainable urban regeneration. RELAND Int. J. Real Estate Land Plan. 2018, 1, 377-384.

6. Liu, J.; Dietz, T.; Carpenter, S.R.; Alberti, M.; Folke, C.; Moran, E.; Pell, A.N.; Deadman, P.; Kratz, T.; Lubchenco, J.; et al. Complexity of coupled human and natural systems. Science 2007, 317, 1513-1516. [CrossRef] [PubMed]

7. Zhang, X.; Li, H. Urban resilience and urban sustainability: What we know and what do not know? Cities 2018, 72, 141-148. [CrossRef]

8. Cohen, M. A systematic review of urban sustainability assessment literature. Sustainability 2017, 9, 2048. [CrossRef]

9. Verma, P.; Raghubanshi, A. Urban sustainability indicators: Challenges and opportunities. Ecol. Indic. 2018, 93, 282-291. [CrossRef]

10. Dizdaroglu, D. Developing micro-level urban ecosystem indicators for sustainability assessment. Environ. Impact Assess. Rev. 2015, 54, 119-124. [CrossRef]

11. Dizdaroglu, D. The role of indicator-based sustainability assessment in policy and the decision-making process: A review and outlook. Sustainability 2017, 9, 1018. [CrossRef]

12. Kotler, P.; Asplund, C.; Rein, I.; Haider, D. Marketing Places Europe: How to Attract Investments, Industries, Residents and Visitors to Cities, Communities, Regions and Nations in Europe; Financial Times: London, UK, 1999.

13. Davoudi, S. European briefing: Polycentricity in European spatial planning: From an analytical tool to a normative agenda. Eur. Plan. Stud. 2003, 11, 979-999. [CrossRef]

14. Oliveira, E. Place Branding in Strategic Spatial Planning: An Analysis at the Regional Scale with Special Reference to Northern Portugal. Ph.D. Thesis, University of Groningen, Groningen, Netherlands, March 2016.

15. Richardson, T.; Jensen, O.B. Discourses of Mobility and Polycentric Development: A Contested View of European Spatial Planning. Eur. Plan. Stud. 2000, 8, 503-520. [CrossRef]

16. Metaxas, T. Place Marketing, Strategic Planning and Competitiveness: The Case of Malta. Eur. Plan. Stud. 2009, 17, 1357-1378. [CrossRef]

17. Warnaby, G.; Medway, D. What about the 'place' in place marketing? Mark. Theory 2013, 13, 345-363. [CrossRef]

18. Gleeson, B.; Low, N. Australian Urban. Planning: New Challenges, New Agendas; Allen \& Unwin: Sydney, Australia, 2000.

19. McGuirk, P.M. Neoliberalist planning? Re-thinking and re-casting Sydney's metropolitan planning. Geogr. Res. 2005, 43, 59-70. [CrossRef]

20. Van Assche, K.; Beunen, R.; Lo, M.C. Place as layered and segmentary commodity: Place branding, smart growth and the creation of product and value. Int. Plan. Stud. 2015, 21, 164-175. [CrossRef]

21. Lucarelli, A. Place branding as urban policy: The (im)political place branding. Cities 2018, 80, 12-21. [CrossRef]

22. García-Falcón, J.M.; Medina-Muñoz, D. The relationship between hotel companies and travel agencies: An empirical assessment of the United States market. Serv. Ind. J. 1999, 19, 102-122. [CrossRef]

23. McClamroch, J.; Byrd, J.; Sowell, L.S. Strategic Planning: Politics, leadership and learning. J. Acad. Libr.-anship 2001, 27, 372-378. [CrossRef]

24. Syrett, S. Local power and economic policy: Local authority economic initiatives in Portugal. Reg. Stud. 1994, 28, 53-67. [CrossRef]

25. Williams, A. Understanding the Hospitality Consumer; Routledge: Oxford, UK, 2012. 
26. Kavaratzis, M.; Ashworth, G. Place marketing: How did we get here and where are we going? J. Place Manag. Dev. 2008, 1, 150-165. [CrossRef]

27. Skinner, H. The emergence and development of place marketing's confused identity. J. Mark. Manag. 2008, 24, 915-928. [CrossRef]

28. Asnawi, A. City Marketing In tourism: A literature review about periodical concept and definition. J. Perspekt. Pembiayaan Dan Pembang. Drh. 2020, 8, 79-90. [CrossRef]

29. Moreno, L.D.R. Sustainable city storytelling: Cultural heritage as a resource for a greener and fairer urban development. J. Cult. Herit. Manag. Sustain. Dev. 2020, 10, 399-412. [CrossRef]

30. Hospers, G.-J. Lynch's The image of the city after 50 years: City marketing lessons from an urban planning classic. Eur. Plan. Stud. 2010, 18, 2073-2081. [CrossRef]

31. Buhalis, D. Marketing the competitive destination of the future. Tour. Manag. 2000, 21, 97-116. [CrossRef]

32. Lobo, B. Chapter 6 Urban Megaprojects and Local Planning Frameworks in New York City, Paris, and Sao Paulo. Available online: https:/ / www.emerald.com/insight/content/doi/10.1108/S1047-0042(2013)0000013011/full/html?skipTracking=true (accessed on 12 November 2020).

33. Theurillat, T.; Crevoisier, O. The sustainability of a financialized urban megaproject: The case of Sihlcity in Zurich. Int. J. Urban. Reg. Res. 2012, 37, 2052-2073. [CrossRef]

34. Pitsis, A.; Clegg, S.; Freeder, D.; Sankaran, S.; Burdon, S. Megaprojects redefined - complexity vs cost and social imperatives. Int. J. Manag. Proj. Bus. 2018, 11, 7-34. [CrossRef]

35. Santamaria, G.D.C. Megaprojects, development and competitiveness: Building the infrastructure for globalization and neoliberalism. Athensj. Soc. Sci. 2019, 6, 263-290. [CrossRef]

36. Rizzo, A. Sustainable urban development and green megaprojects in the Arab states of the Gulf Region: Limitations, covert aims, and unintended outcomes in Doha, Qatar. Int. Plan. Stud. 2017, 22, 85-98. [CrossRef]

37. Moreno-Jiménez, A.; Cañada-Torrecilla, R.; Vidal-Domínguez, M.J.; Palacios-García, A.; Martínez-Suárez, P. Assessing environmental justice through potential exposure to air pollution: A socio-spatial analysis in Madrid and Barcelona, Spain. Geoforum 2016, 69, 117-131. [CrossRef]

38. Carabante, B. Madrid ante el reto de una movilidad sostenible. Economistas 2020, 169, 80-86.

39. Rondelez, P.; Medina García, C. Limits of Municipalism. What can we Learn from Operación Chamartín? Available online: https: / /lirias.kuleuven.be/3083168?limo=0 (accessed on 12 November 2020).

40. Distrito Castellana Norte: Accesibilidad, Movilidad, Sostenibilidad y Tecnología, Pilares de la Ciudad del siglo XXI. 2018. Available online: https:/ / distritocastellananorte.com/accesibilidad-movilidad-sostenibilidad-y-tecnologia-pilares-de-la-ciudaddel-siglo-xxi/ (accessed on 12 November 2020).

41. Expansión News. Madrid, Nuevo Norte: Así será finalmente la Operación Chamartín Aprobada el Jueves. Available online: https: //www.expansion.com/empresas/inmobiliario/2017/07/27/5979b0b4e2704ed3038b4609.html (accessed on 12 November 2020).

42. DCN Presenta su Memoria de Compromiso Social. Available online: https://distritocastellananorte.com/dcn-presenta-sumemoria-de-compromiso-social/ (accessed on 12 November 2020).

43. The Sustainable Development Goals Report 2018. Available online: https://unstats.un.org/sdgs/files/report/2018 /TheSustainableDevelopmentGoalsReport2018-EN.pdf (accessed on 12 November 2020).

44. Distrito Castellana Norte: Madrid Nuevo Norte, Urbanismo Alineado con los Objetivos de Desarrollo Sostenible. Available online: https:/ / distritocastellananorte.com/madrid-nuevo-norte-urbanismo-alineado-con-los-objetivos-de-desarrollosostenible/\#1586184757222-9e6f8731-47d5 (accessed on 12 November 2020).

45. Nunes, A.R.; Lee, K.; O'Riordan, T. The importance of an integrating framework for achieving the sustainable development goals: The example of health and well-being. BMJ Glob. Health 2016, 1, e000068. [CrossRef]

46. Grosser, K. Corporate social responsibility and gender equality: Women as stakeholders and the European Union sus-tainability strategy. Bus. Ethics A Eur. Rev. 2009, 18, 290-307. [CrossRef]

47. Kayaga, S.; Smout, I.; Al-Maskati, H. Water demand management-shifting urban water management towards sustainability. Water Sci. Technol. Water Supply 2007, 7, 49-56. [CrossRef]

48. Owusu, P.A.; Asumadu-Sarkodie, S. A review of renewable energy sources, sustainability issues and climate change mitigation. Cogent Eng. 2016, 3, 1167990. [CrossRef]

49. Arias-Molinares, D.; García-Palomares, J.C. Shared mobility development as key for prompting mobility as a service (MaaS) in urban areas: The case of Madrid. Case Stud. Transp. Policy 2020, 8, 846-859. [CrossRef]

50. Ampudia-Renuncio, M.; Guirao, B.; Molina-Sánchez, R.; Braganza, L. Electric free-floating carsharing for sustainable cities: Characterisation of frequent trip profiles using acquired rental data. Sustainability 2020, 12, 1248. [CrossRef]

51. Mozos-Blanco, M.Á.; Pozo-Menéndez, E.; Arce, R.; Baucells-Aletà, N. The way to sustainable mobility. A comparative analysis of sustainable mobility plans in Spain. Transp. Policy 2018, 72, 45-54. [CrossRef]

52. Twisse, F. Guidelines for Developing and Implementing a Sustainable Urban Mobility Plan (2nd edition). Available online: https: / / www.eltis.org/guidelines/second-edition-sump-guidelines (accessed on 12 November 2020).

53. Plan de Movilidad Sostenible y Espacio Público (PMSyEP). Available online: https://www.madrid.es/portales/munimadrid/ es/Inicio/Movilidad-y-transportes/Plan-de-Movilidad-Sostenible-y-Espacio-Publico-PMSyEP-/?vgnextfmt=default\& vgnextoid=203f35e7f4779610VgnVCM1000001d4a900aRCRD\&vgnextchannel=220e31d3b28fe410VgnVCM1000000b205a0 aRCRD (accessed on 12 November 2020). 
54. Visvizi, A.; Lytras, M.D.; Damiani, E.; Mathkour, H. Policy making for smart cities: Innovation and social inclusive economic growth for sustainability. J. Sci. Technol. Policy Manag. 2018, 9, 126-133. [CrossRef]

55. Cascetta, E.; Pagliara, F. Le Infrastrutture di Trasporto in Italia: Cosa non ha Funzionato e Come Porvi Rimedio. Available online: https://www.sipotra.it/old/wp-content/uploads/2015/05/recensione-libro-Cascetta-FerPress.pdf (accessed on 12 November 2020).

56. Bailey, D. The environmental paradox of the welfare state: The dynamics of sustainability. New Politi- Econ. 2015, $20,793-811$. [CrossRef]

57. Kenworthy, J.R. The eco-city: Ten key transport and planning dimensions for sustainable city development. Environ. Urban 2006, 18, 67-85. [CrossRef]

58. Buerke, A.; Straatmann, T.; Lin-Hi, N.; Müller, K. Consumer awareness and sustainability-focused value orientation as motivating factors of responsible consumer behavior. Rev. Manag. Sci. 2017, 11, 959-991. [CrossRef]

59. Gills, B.; Morgan, J. Global climate emergency: After COP24, climate science, urgency, and the threat to humanity. Globalizations 2019, 17, 885-902. [CrossRef]

60. Pardo, G.; Del Prado, A. Guidelines for small ruminant production systems under climate emergency in Europe. Small Rumin. Res. 2020, 193, 106261. [CrossRef]

61. Pecl, G.T.; Araújo, M.B.; Bell, J.D.; Blanchard, J.; Bonebrake, T.C.; Chen, I.-C.; Clark, T.D.; Colwell, R.K.; Danielsen, F.; Evengård, B.; et al. Biodiversity redistribution under climate change: Impacts on ecosystems and human well-being. Science 2017, 355, eaai9214. [CrossRef]

62. Durmaz, A.; Bayramoğlu, T. Sustainablity in economics. In Studies on Sustainability Research; Başar, E.E., Bayramoğlu, T., Eds.; Lambert Academic Publishing: Saarbrücken, Germany, 2017.

63. Distrito Castellana Norte: Madrid Nuevo Norte, Una Nueva Norma de Hacer Urbanismo. 2017. Available online: https: / / distritocastellananorte.com/madrid-nuevo-norte-una-nueva-forma-de-hacer-urbanismo/ (accessed on 12 November 2020).

64. Malhotra, N.; Birks, D. Marketing Research: An applied Approach, 2nd European ed.; Pearson Education: London, UK, 2003.

65. Malhotra, N.; Birks, D. Marketing research: An applied Approach, 3rd European ed.; Pearson Education: London, UK, 2006.

66. Meng, F.; Tepanon, Y.; Uysal, M. Measuring tourist satisfaction by attribute and motivation: The case of a nature-based resort. J. Vacat. Mark. 2008, 14, 41-56. [CrossRef]

67. He, Q.; Chen, X.; Wang, G.; Zhu, J.; Yang, D.; Liu, X.; Li, Y. Managing social responsibility for sustainability in mega-projects: An innovation transitions perspective on success. J. Clean. Prod. 2019, 241, 118395. [CrossRef]

68. Ringle, C.M.; Wende, S.; Becker, J.-M. SmartPLS 3; SmartPLS GmbH: Boenningstedt, Germany, 2015; Available online: http: / / www.smartpls.com (accessed on 12 November 2020).

69. Ugwu, O.; Haupt, T. Key performance indicators and assessment methods for infrastructure sustainability-A South African construction industry perspective. Build. Environ. 2007, 42, 665-680. [CrossRef]

70. Nair, A.; Nayar, S.K. Key performance indicators of sustainability. IOP Conf. Ser. Earth Environ. Sci. 2020, 491, 012047. [CrossRef]

71. Song, Y.; Hou, D.; Zhang, J.; O'Connor, D.; Li, G.; Gu, Q.; Li, S.; Liu, P. Environmental and socio-economic sustainability appraisal of contaminated land remediation strategies: A case study at a mega-site in China. Sci. Total. Environ. 2018, 610, 391-401. [CrossRef] [PubMed]

72. Xing, Y.; Horner, R.M.W.; El-Haram, M.A.; Bebbington, J. A framework model for assessing sustainability impacts of urban development. Account. Forum 2009, 33, 209-224. [CrossRef]

73. Li, H.; Zhang, X.; Ng, S.T.; Skitmore, M.; Dong, Y.H. Social sustainability indicators of public construction megaprojects in China. J. Urban Plan. Dev. 2018, 144, 04018034. [CrossRef]

74. Karji, A.; Woldesenbet, A.; Khanzadi, M.; Tafazzoli, M. Assessment of social sustainability indicators in mass housing construction: A case study of mehr housing project. Sustain. Cities Soc. 2019, 50, 101697. [CrossRef]

75. Banihashemi, S.; Hosseini, M.R.; Golizadeh, H.; Sankaran, S. Critical success factors (CSFs) for integration of sus-tainability into construction project management practices in developing countries. Int. J. Project Manag. 2017, 35, 1103-1119. [CrossRef]

76. Boateng, P.; Chen, Z.; Ogunlana, S.O. An Analytical Network Process model for risks prioritisation in megaprojects. Int. J. Proj. Manag. 2015, 33, 1795-1811. [CrossRef]

77. Wu, G.; Li, H.; Wu, C.; Hu, Z. How different strengths of ties impact project performance in megaprojects: The mediating role of trust. Int. J. Manag. Proj. Bus. 2020, 13, 889-912. [CrossRef]

78. Meijers, E.; Hoekstra, J.; Aguado, R. Strategic planning for city networks: The emergence of a Basque Global City? Int. Plan. Stud. 2008, 13, 239-259. [CrossRef]

79. Lee, J.H.; Ostwald, M.J.; Sher, W.D.; Lee, H. Developing strategic planning schemes for urban regeneration through mixed-use development in Seoul. Int. Plan. Stud. 2017, 22, 205-225. [CrossRef]

80. $\mathrm{Xu}, \mathrm{J}$. Governing city-regions in China: Theoretical issues and perspectives for regional strategic planning. Town Plan. Rev. 2008, 79, 157-186. [CrossRef]

81. Tsenkova, S. Reinventing Strategic Planning in Post-socialist Cities: Experiences from Sofia. Eur. Plan. Stud. 2007, 15, $295-317$. [CrossRef]

82. Partidärio, M.R.; Paddon, M.; Eggenberger, M.; Chau, D.M.; Van Duyen, N. Linking strategic environmental assessment (SEA) and city development strategy in Vietnam. Impact Assess. Proj. Apprais. 2008, 26, 219-227. [CrossRef] 
83. Young, R.F. Planting the living city: Best practices in planning green infrastructure-Results from major us cities. J. Am. Plan. Assoc. 2011, 77, 368-381. [CrossRef]

84. Kim, J.I. Making cities global: The new city development of Songdo, Yujiapu and Lingang. Plan. Perspect. 2013, 29, 329-356. [CrossRef]

85. Cavenago, D.; Trivellato, B. Organizing strategic spatial planning: Experiences from Italian cities. Space Polity 2010, 14, 167-188. [CrossRef]

86. Metaxas, T. Cities competition, place marketing and economic development in South Europe: The Barcelona case as FDI destination. Theor. Empir. Res. Urban Manag. 2010, 5, 5-19.

87. Percoco, M. Strategic Planning and Institutional Collective Action in Italian Cities. Public Manag. Rev. 2014, 18, 1-20. [CrossRef]

88. Oliveira, E. Place branding as a strategic spatial planning instrument: A theoretical framework to branding regions with references to northern Portugal. J. Place Manag. Dev. 2016, 9, 47-72. [CrossRef]

89. Deffner, A.; Metaxas, T.; Arvanitidis, P. Developing place marketing pilot plans in northern Europe: The cases of Rostock (Germany) and Kainuu (Finland). An Int. J. Hosp. Tour. 2013, 24, 241-263.

90. Carlisle, S.; Johansen, A.; Kunc, M. Strategic foresight for (coastal) urban tourism market complexity: The case of Bournemouth. Tour. Manag. 2016, 54, 81-95. [CrossRef]

91. Angelevska-Najdeska, K.; Rakicevik, G. Planning of sustainable tourism development. Procedia - Soc. Behav. Sci. 2012, 44, 210-220. [CrossRef]

92. Searle, G. 'Relational' planning and recent Sydney metropolitan and city strategies. Urban Policy Res. 2013, 31, 367-378. [CrossRef]

93. Spahiu, L.; Kopacek, P. Strategic planning in small and medium enterprises at tourism sector in Kosovo. IFAC Proc. Vol. 2010, 43, 123-127. [CrossRef]

94. Risteskia, M.; Kocevskia, J.; Arnaudov, K. Spatial planning and sustainable tourism as basis for developing competitive tourist destinations. Procedia- Soc. Behav. Sci. 2012, 44, 375-386. [CrossRef]

95. Kamble, Z.; Bouchon, F. Tourism planning and a nation's vision: A review of the tourism policy of Sri Lanka. Procedia-Soc. Behav. Sci. 2014, 144, 229-236. [CrossRef]

96. Jamhawi, M.M.; Hajahjah, Z.A. A bottom-up approach for cultural tourism management in the old city of As-Salt, Jordan. J. Cult. Herit. Manag. Sustain. Dev. 2017, 7, 91-106. [CrossRef]

97. De Luca, S. Public engagement in strategic transportation planning: An analytic hierarchy process based approach. Transp. Policy 2014, 33, 110-124. [CrossRef]

98. Burt, G.; Mackay, D.J.; Van Der Heijden, K.; Verheijdt, C. Openness disposition: Readiness characteristics that influence participant benefits from scenario planning as strategic conversation. Technol. Forecast. Soc. Chang. 2017, 124, 16-25. [CrossRef] 